\title{
Article \\ Intellectual Structure and Evolution of Accounting Conservatism Research: Past Trends and Future Research Suggestions
}

\author{
Umair Bhutta ${ }^{1}$, Jéssica Nunes Martins ${ }^{2,3}$, Mário Nuno Mata ${ }^{4,5}{ }^{(0)}$, Ali Raza ${ }^{6, *}\left(\mathbb{C}\right.$, Rui Miguel Dantas ${ }^{5} \mathbb{C}^{\text {, }}$ \\ Anabela Batista Correia ${ }^{5}\left({ }^{-1}\right.$ and Muhammad Rafiq ${ }^{7}$
}

check for updates

Citation: Bhutta, Umair, Jéssica Nunes Martins, Mário Nuno Mata, Ali Raza, Rui Miguel Dantas, Anabela Batista Correia, and Muhammad Rafiq. 2021. Intellectual Structure and Evolution of Accounting Conservatism Research: Past Trends and Future Research Suggestions. International Journal of Financial Studies 9: 35. https://doi.org/ $10.3390 /$ ijfs 9030035

Academic Editor:

Sorinel Capusneanu

Received: 31 March 2021

Accepted: 23 June 2021

Published: 30 June 2021

Publisher's Note: MDPI stays neutral with regard to jurisdictional claims in published maps and institutional affiliations.

Copyright: (c) 2021 by the authors. Licensee MDPI, Basel, Switzerland. This article is an open access article distributed under the terms and conditions of the Creative Commons Attribution (CC BY) license (https:/ / creativecommons.org/licenses/by/ $4.0 /)$.
1 Business Administration Department, University of Technology and Applied Sciences, Ibri 516, Oman; umair_444@hotmail.com

2 NOVA Information Management School (NOVA IMS), Universidade Nova de Lisboa, 1099-085 Lisbon, Portugal; jessicanunesmartins@gmail.com

3 BPI-Banco Portugês de Investimento-CaixaBank Group, Accounting Department, Largo Jean Monnet $19^{\circ}$ andar, 1269-067 Lisboa, Portugal

4 School of Management and Technology (ESGTS-IPS), Polytechnic Institute of Santarém, 2001-904 Santarém, Portugal; mnmata@iscal.ipl.pt

5 ISCAL-Instituto Superior de Contabilidade e Administração de Lisboa, Instituto Politécnico de Lisboa, 1069-035 Lisboa, Portugal; rmdantas@iscal.ipl.pt (R.M.D.); ambatista@iscal.ipl.pt (A.B.C.)

6 Knowledge Unit of Business, Economics, Accountancy and Commerce, University of Management and Technology, Sialkot, Pakistan

7 Economics and Business Administration, Vehari Campus, University of Education, Lahore, Pakistan; rafiqcw@yahoo.com

* Correspondence: ali_khawaja818@hotmail.com

Abstract: Accounting conservatism (AC) is one of the components of financial reporting, and has been widely studied by academicians to identify its impact on information quality. Scholars in accounting have started to explore how AC is related to different fundamental functional areas of organizations. The interest of the scholars has resulted in an increasing number of publications in this field. In this study, we examined 408 indexed publications related to AC. This work's objectives include analyzing the regional distribution, size, and evolution of this knowledge base by identifying key authors, documents, and journals while exploring current literature, scholarly structure, and highlighting contemporary trends. The findings of the study concluded that most of the studies are conducted in developed nations contexts. However, there are still areas that need further exploration to obtain more profound insights on the subject. This bibliometric review inspires a new generation of researchers on the topic by giving them an overview of the past studies related to AC.

Keywords: accounting conservatism; bibliometric analysis; co-citation; bibliographic coupling; $\mathrm{CO}_{-}$ occurrence

\section{Introduction}

Accounting conservatism $(\mathrm{AC})$ is one of the components of financial reporting, and has been widely studied by academicians to identify its impact on information quality (Sterling 1982). It is defined as "accounting policies to show the net asset value of assets downward relative to the economic utility of the assets". For tangible and intangible assets, accounting standards have conservatism principles, such as impairment accounting and lower cost or market (Kabir and Laswad 2014). In the last two decades, the topic has garnered academicians' interest, and the results suggest that financial reporting is conservative (Basu 1997; Watts 2003). Still, the joint framework proposed by International Accounting Standards Board (IASB) and the Financial Accounting Standard Board (FASB) has not included conservatism as one of the characteristics of reporting principle (FASB 2010), even though conservatism plays a crucial role in financial reporting. There is still a debate among 
researchers and regulators on the extent that conservatism is beneficial or costly to users of financial reports. Researchers have conflicting views about the concept of AC, and some echoed the notion that conservatism biases financial statement figures downward (Gigler et al. 2009; Guay and Verrecchia 2006). On the other hand, some researchers believe conservatism naturally arises among different parties, and it helps maintain an efficient contracting mechanism (Basu 1997; Watts 2003). In this review, we will look at the studies focused on AC and see different aspects of the research conducted on the issue.

The recent decade has seen the growing importance of accounting conservatism research. For instance, previous literature has suggested that the use of AC improved the investment efficiency of an organization (Lara et al. 2016) and enhanced stock value during the crisis period (Francis et al. 2013). It also helps in reducing the information asymmetries, which then improves IPO pricing (Boulton et al. 2017). Scholars also discussed the negative impact of AC on firms. For instance, Chang et al. (2013) argued that AC might hamper innovation performance, and managers might make less risky decisions due to market pressure. The studies also classified accounting conservatism into conditional and unconditional conservatism and discussed features of both (Khalilov and Osma 2020). In addition to these quantitative studies, several qualitative studies (Glover and Lin 2018) have also been conducted.

Moreover, many researchers studied the antecedents of the AC and how it is affected by different factors (Ahmed and Duellman 2013; Ho et al. 2015; Li 2013). As a result, the study on AC has increased exponentially. This study reviews the different factors associated with accounting conservatism.

Even though the AC concept has increasingly received attention from practitioners and researchers, this research area suffers from a lack of comprehensive bibliometric analysis. Hence, this research applies bibliometric techniques to explore how scholarly literature on AC is being developed. The bibliometric methodology makes it possible to give shape, structure, and direction to the research domain as it grows and advances. Bibliometric techniques also allow us to analyze articles and citations employed by scholars in their studies. This study aims to recognize and evaluate the main articles' impact, relationships, and critical contributions regarding AC.

As a result, the present study contributes to identifying the theoretical grounding, most relevant authors, the topics already covered, and new perspectives and lines for future investigation. Moreover, the present paper analyzes popular issues, research trends, chronological development, and key outcomes of AC. For accompanying this purpose, the present study employs the Scopus database, which contains 408 publications until 2019. This paper focuses exclusively on analyzing the publications on the topic of AC from 1994 to 2019 to evaluate their scholarly impact. These 408 publications are devoted to investigating AC during the period.

The remainder of the current study is structured as follows: The next section discusses a comprehensive literature review regarding $\mathrm{AC}$ and its influence in accounting management. The third section describes the method adopted to conduct the bibliometric study, while the fourth section describes the findings of bibliometric analysis. In the final section, study implications, research limitations, and possible future research directions are given.

\section{Methods}

\section{Scientific Tools and Support}

Bibliometric studies (Björk et al. 2014; Bouyssou and Marchant 2011; Cadavid Higuita et al. 2012; Daim et al. 2006; De Bakker et al. 2005; Donthu et al. 2020; Duque-Oliva et al. 2006; Durieux and Gevenois 2010; Farrukh et al. 2021; Garfield 2006; Gu et al. 2021; Kessler 1963; Merigó et al. 2016; Nerur et al. 2008; Persson et al. 2009; Pilkington and Meredith 2009; Small 1973; Van Eck and Waltman 2010), also known as quantitative bibliographic analysis, aid in the exploration and organization of published work in a particular subject or domain of study (Farrukh et al. 2021; Gu et al. 2021). Bibliometric studies involve counting citations in existing literature articles and using those counts to create a statistical distribution 
(Farrukh et al. 2021, Farrukh et al. 2020). The research makes use of published articles to look at the trends and patterns of what has been published in a particular topic (Gao et al. 2020; Wu et al. 2021). The bibliometric approach is an important component in evaluating published research articles. Reports, books, and a collection of other relevant sources may be analyzed using bibliometric methods (Farrukh et al. 2020; Nawaz et al. 2020). The primary goal of bibliometric analysis is to examine patterns and trends in current research (Ahmed et al. 2021; Nawaz et al. 2020). In this study we used bibliometric technique to analyze the publication structure of accounting conservatism research.

To extract publications on accounting conservatism we run a search using query: (TITLE-ABS-KEY("ACCOUNTING CONSERVATISM") in the web of sciences and Scopus database, our search showed that there are 304 publications in web of sciences whereas Scopus record showed 408 publications, thus given this significant difference in number of publications we extracted bibliographic data from the Scopus database. VOSviewer software was used to construct the bibliographic coupling as well as co-authorship maps. VOSviewer software has been widely used in the previous bibliometric studies.

\section{Results}

\subsection{Publication Trend}

The result (Figure 1) illustrates the evolution of a number of publications on AC from 1994 to 2019. This demonstrates that the early era from 1994 to 2010 saw a dearth of publications. From Table 1 we can notice that between 2011 and 2020, the number of articles climbed dramatically. Between 2015 and 2019, the highest number of publications was recorded. Figure 1 demonstrates an increase in the publishing of studies on AC. According to the statistics, the most prolific year was 2019, with 56 publications and 1624 citations. These statistics demonstrate that $\mathrm{AC}$ research is gaining traction, although at a slower pace than comparable areas in management and strategy. Due to the fact that $\mathrm{AC}$ is garnering the attention of policymakers and academics, we anticipate an increase in the number of studies conducted in this subject.

\section{Documents by year}

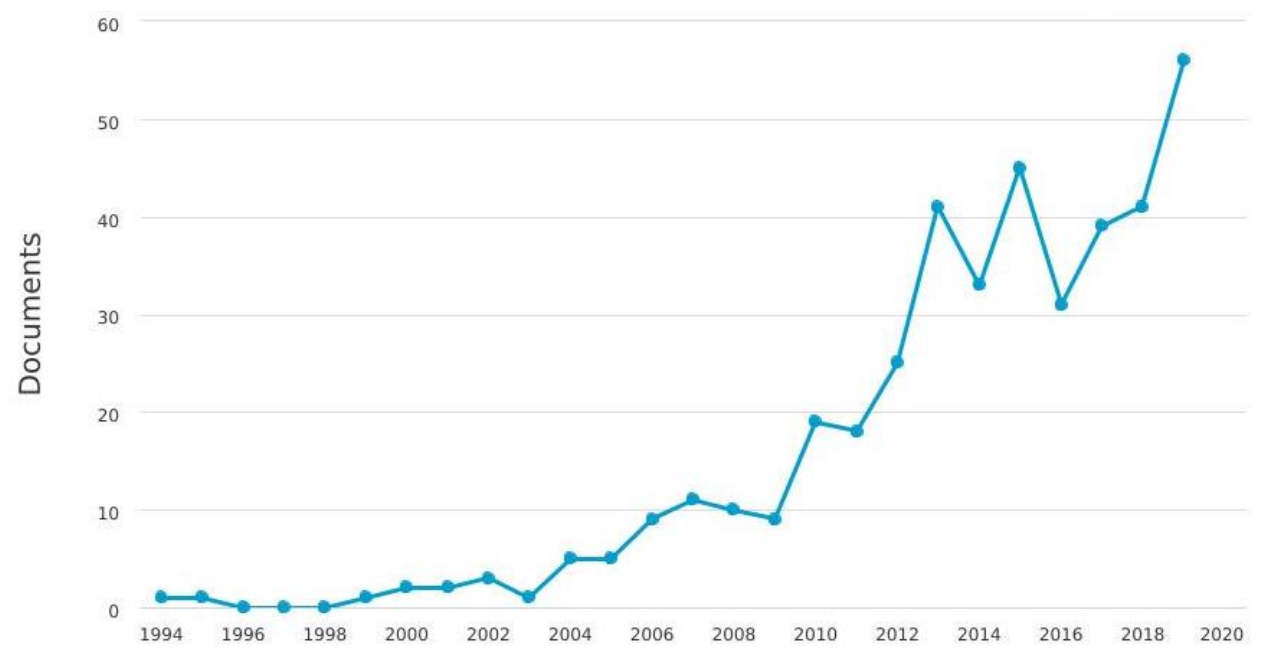

Figure 1. Documents by year. 
Table 1. Trends of publication and citations.

\begin{tabular}{lcc}
\hline Year & Publication & Citations \\
\hline 2019 & 56 & 1624 \\
2018 & 41 & 1240 \\
2017 & 39 & 967 \\
2016 & 31 & 955 \\
2015 & 45 & 856 \\
2014 & 33 & 627 \\
2013 & 41 & 609 \\
2012 & 25 & 409 \\
2011 & 18 & 430 \\
2010 & 19 & 297 \\
2009 & 9 & 210 \\
2008 & 10 & 154 \\
2007 & 11 & 115 \\
2006 & 9 & 82 \\
2005 & 5 & 83 \\
2004 & 5 & 47 \\
2003 & 1 & 50 \\
2002 & 3 & 36 \\
2001 & 2 & 33 \\
2000 & 2 & 29 \\
1999 & 1 & 25 \\
1998 & 0 & 14 \\
1997 & 0 & 14 \\
1996 & 0 & 14 \\
1995 & 1 & 2 \\
1994 & 408 & 8922 \\
Total & &
\end{tabular}

\subsection{Countries and Languages of Publications}

To get a sense of the most prolific countries, we studied the number of papers published by contributing countries. Although publications came from 41 nations across the globe, the majority of this scholarly contribution came from the USA, China, and the UK. Table 2 presents the results of the top 10 contributing nations.

Table 2. The most productive countries.

\begin{tabular}{ccc}
\hline Rank & Country & Total Publications \\
\hline 1 & United States & 156 \\
2 & China & 71 \\
3 & United Kingdom & 39 \\
4 & Canada & 31 \\
5 & Australia & 30 \\
6 & South Korea & 23 \\
7 & Hong Kong & 20 \\
8 & Spain & 20 \\
9 & Iran & 17 \\
10 & Taiwan & 15 \\
\hline
\end{tabular}

We established a bibliometric coupling to better understand the networking across the nations publishing in AC. It happens when two documents both reference a third research. When a document from two distinct nations references the third document in their publications, this is known as bibliometric coupling. It demonstrates how researchers from various nations and writers use comparable literature in their studies.

The bibliometric coupling findings are shown in Figure 2; each circle represents a nation, and the size of the circle denotes the contribution. The more the input, the larger the size. Figure 2 depicts three groupings based on the papers' bibliographic coupling. The 
United Kingdom leads the green cluster, while the United States, Australia, and China dominate the red cluster. France and Tunisia are part of the blue color cluster. Another fascinating topic is how authors from other countries have collaborated with authors from other countries. We do a co-authorship analysis with nations.

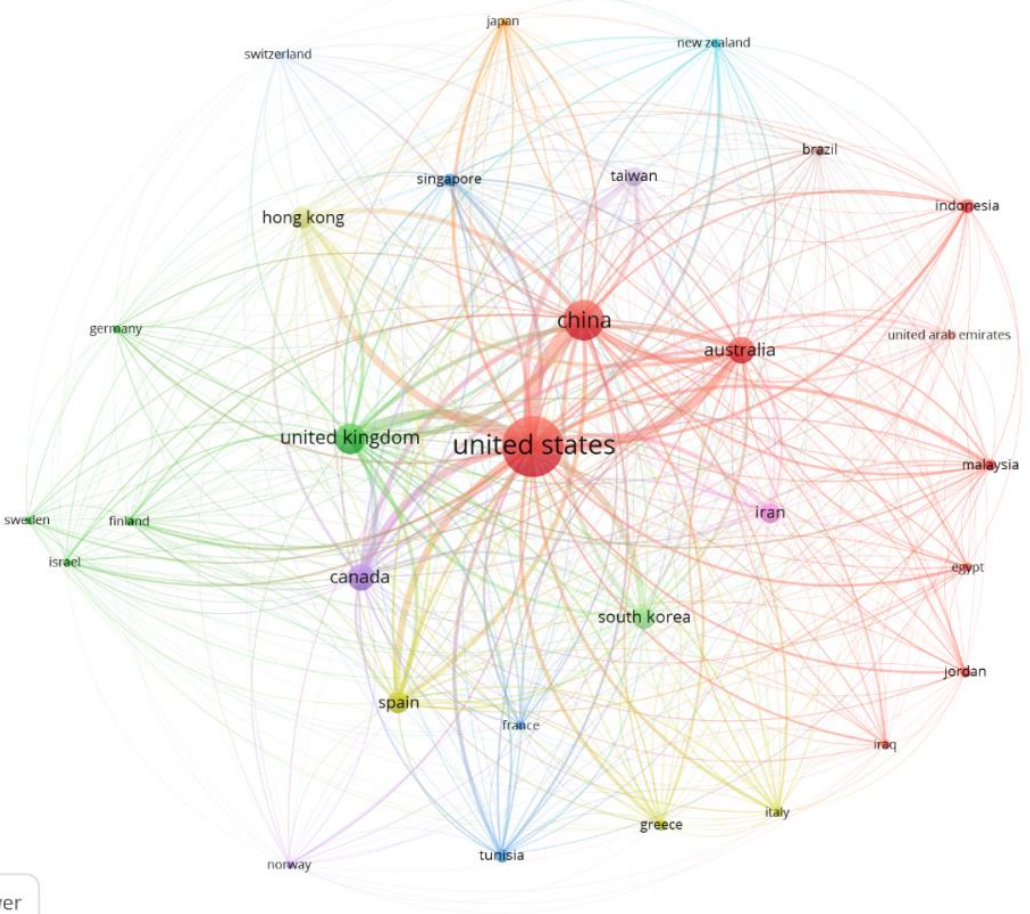

\& vosviewer

Figure 2. BC of countries.

In the case of nations, Figure 3 illustrates the co-authorship arrangement. Remember that by examining co-authorship, we can determine a country's total number of publications and the key ties it has with other nations. Figure 3 illustrates the co-authorship network in a different color. China has significant ties to Australia and Taiwan (China), whereas the UK has significant ties to Spain and Tanzania. Similarly, the United States of America has a strong co-authorship relationship with South Korea and Singapore. These findings are based on a country's five mandatory papers.

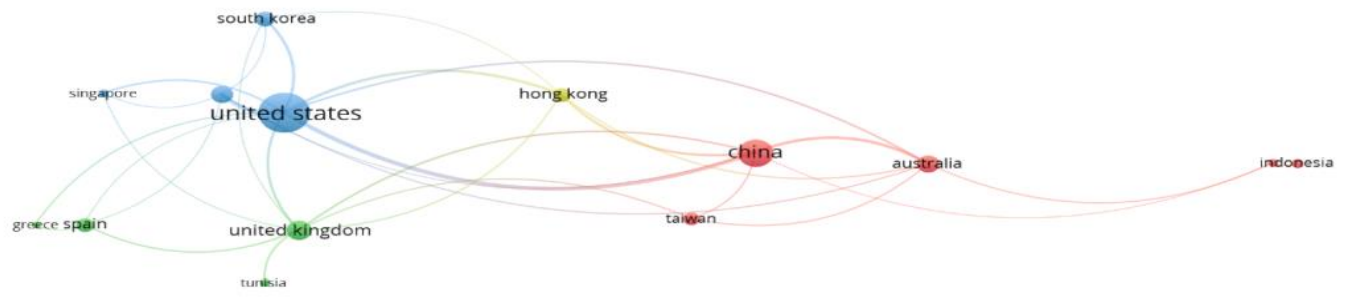

Figure 3. Co-authorship among countries. 


\subsection{The Most Productive Universities}

The critical aspect of the bibliometric analysis is to see which are the most productive institutes or universities are involved in researching a topic. Table 3 shows that National Taiwan University the most productive university with seven document publications. The University of Houston is ranked 2nd with seven publications, while the University of Missouri Terengganu shares the 3rd rank with seven documents each. Based on the citation, National Taiwan University ranked 1st as its seven documents obtain more citations than other universities with the same publications.

Table 3. Five the most productive Universities.

\begin{tabular}{ccc}
\hline Rank & Name of Institute & No. of Documents \\
\hline 1. & National Taiwan University & 7 \\
2. & University of Houston & 7 \\
3. & University of Missouri & 7 \\
4. & The University of Texas at Austin & 7 \\
5. & MIT Sloan School of Management & 7 \\
6. & Islamic Azad University & 7 \\
7. & Universidad Carlos III de Madrid & 6 \\
8. & University of Valencia & 6 \\
9. & Korea University & 6 \\
10. & Hong Kong University of Science and Technology & 6 \\
\hline
\end{tabular}

\subsection{Leading Journals}

The research papers are an excellent source for readers to obtain information regarding discoveries, innovations, new trends and learn about opportunities to research a specific topic. The published researches in the peer review journals are reviewed and endorsed by the experts of the field. The rigorous review process makes these peer-reviewed papers a reliable source of information for scholars, policymakers, and all other concerned people. The studies in these journals are sources of vast scientific information that help researchers extend the study on the particular field. The scientific journal provides a platform to researchers to share ideas and generate new ideas in the field of study. They also help to sequence studies on the particular topic with the help of these journal publications. The researchers are looking for recognition for their work, and these journal publications recognize the researcher's contribution to the field. The researchers can increase prospects of development in their careers by publishing their work in top-quality journals.

As there is a revolution in information technology, it also impacts the field of education and research. The revolution in technology facilitates the launch of new journals, and in the last two decades, there is an exponential rise in the number of new journals. This growth in the number of journals challenges the researchers to locate and classify the most relevant journals in the particular study area. Additionally, due to multidisciplinary journals, those accept papers from multiple fields, make it more challenging to search for the relevant research paper for specific purposes. This section lists the most active and relevant journals publishing and contributing on the topic of accounting conservatism.

The articles included in this study are published in 91 journals and conferences, although most of these publications came from only 17 journals. Table 4 presents the journals list that published AC research. Contemporary Accounting Research is the top journal with 23 publications, followed by the Journal of Accounting and Economics with 20 papers on AC between 2000 to 2019. The Journal of Business Finance and Accounting ranked 3rd with 18 publications. Accounting Review and Review of Accounting Studies come at 4th and 5th, having 17 and 16 publications, respectively. 
Table 4. Top productive journals that publish AC research.

\begin{tabular}{ccc}
\hline Rank & Title & NP \\
\hline 1 & Contemporary Accounting Research & 23 \\
2 & Journal Of Accounting And Economics & 20 \\
3 & Journal Of Business Finance And Accounting & 18 \\
4 & Accounting Review & 17 \\
5 & Review Of Accounting Studies & 16 \\
6 & European Accounting Review & 13 \\
7 & Journal Of Accounting Research & 11 \\
8 & Journal Of Applied Business Research & 11 \\
9 & Accounting And Finance & 10 \\
10 & Journal Of Accounting And Public Policy & 8 \\
11 & Journal Of Accounting Auditing And Finance & 8 \\
12 & Review Of Quantitative Finance And Accounting & 8 \\
13 & Accounting Horizons & 7 \\
14 & Journal Of International Accounting Auditing And Taxation & 6 \\
15 & Asian Review Of Accounting & 5 \\
16 & International Journal Of Accounting And Information Management & 5 \\
\hline
\end{tabular}

\subsection{The Most Productive Authors in AC}

To see who publishes most frequently in AC, we present results in Table 5. Lobo, G.J. tops the list with six publications and 172 citations to these publications. It is followed by Pae, J.and Ahmed, A.S. with six publications and five publications each. In terms of citations, Ahmed, A.S. takes the lead with 842 citations in 5 publications.

Table 5. The most productive authors in AC.

\begin{tabular}{|c|c|c|c|c|}
\hline Rank & Authors & Affiliation & No. Papers & TC \\
\hline 1. & Lobo, G.J. & $\begin{array}{c}\text { C. T. Bauer College of Business, Department of } \\
\text { Accountancy and Taxation, Houston, } \\
\text { United States }\end{array}$ & 6 & 172 \\
\hline 2. & Pae, J. & Korea University, Seoul, South Korea & 6 & 127 \\
\hline 3. & Ahmed, A.S. & $\begin{array}{c}\text { Texas AandM University, College Station, } \\
\text { United States }\end{array}$ & 5 & 842 \\
\hline 4. & Zhang, F. & $\begin{array}{c}\text { The University of Queensland, Brisbane, } \\
\text { Australia }\end{array}$ & 5 & 89 \\
\hline
\end{tabular}

\subsection{The Most Cited Publication}

Table 6 shows the most cited source or reference on the topic. It is another important aspect of judging the performance of authors or journal. In this section, we identified the most cited publications. For this, we depended upon the data collected from the Scopus database. We followed the same protocol, as stated in the method section. This provided us with a list of all those publications which have AC in their title, abstract, or in keywords. We selected all publications with 50 or more citations.

The Feltham and Ohlson (1995) paper "Valuation and Clean Surplus Accounting for Operating and Financial Activities" got the highest citation number. This paper investigated the relationship between a firm's market value and accounting data linking operating and financial activities. They asserted that due to conservative accounting practices, the organization was not altering the future cash flow. Consequently, it did not affect the market value of equity. The authors of the study also developed a model to measure accounting conservatism. 
Table 6. The most cited publication.

\begin{tabular}{|c|c|c|c|c|}
\hline Authors & Title & Year & Source Title & Cited by \\
\hline $\begin{array}{l}\text { FELTHAM G.A., } \\
\text { OHLSON J.A. }\end{array}$ & $\begin{array}{c}\text { Valuation and Clean Surplus Accounting for Operating } \\
\text { and Financial Activities }\end{array}$ & 1995 & $\begin{array}{c}\text { Contemporary } \\
\text { Accounting Research }\end{array}$ & 853 \\
\hline $\begin{array}{l}\text { Barth M.E., Beaver W.H., } \\
\text { Landsman W.R. }\end{array}$ & $\begin{array}{l}\text { The relevance of the value relevance literature for } \\
\text { financial accounting standard setting: Another view }\end{array}$ & 2001 & $\begin{array}{l}\text { Journal of Accounting } \\
\text { and Economics }\end{array}$ & 578 \\
\hline Francis J.R., Wang D. & $\begin{array}{c}\text { The joint effect of investor protection and big } 4 \text { audits on } \\
\text { earnings quality around the world }\end{array}$ & 2008 & $\begin{array}{c}\text { Contemporary } \\
\text { Accounting Research }\end{array}$ & 394 \\
\hline Khan M., Watts R.L. & $\begin{array}{c}\text { Estimation and empirical properties of a firm-year } \\
\text { measure of accounting conservatism }\end{array}$ & 2009 & $\begin{array}{l}\text { Journal of Accounting } \\
\text { and Economics }\end{array}$ & 383 \\
\hline Penman S.H., Zhang X.-J. & $\begin{array}{c}\text { Accounting conservatism, the quality of earnings, and } \\
\text { stock returns }\end{array}$ & 2002 & Accounting Review & 334 \\
\hline $\begin{array}{l}\text { Ahmed A.S., Billings B.K., } \\
\text { Morton R.M., } \\
\text { Stanford-Harris M. }\end{array}$ & $\begin{array}{c}\text { The role of accounting conservatism in mitigating } \\
\text { bondholder-shareholder conflicts over dividend policy } \\
\text { and in reducing debt costs }\end{array}$ & 2002 & Accounting Review & 315 \\
\hline Zhang J. & $\begin{array}{c}\text { The contracting benefits of accounting conservatism to } \\
\text { lenders and borrowers }\end{array}$ & 2008 & $\begin{array}{l}\text { Journal of Accounting } \\
\text { and Economics }\end{array}$ & 299 \\
\hline Ahmed A.S., Duellman S. & $\begin{array}{l}\text { Accounting conservatism and board of director } \\
\text { characteristics: An empirical analysis }\end{array}$ & 2007 & $\begin{array}{l}\text { Journal of Accounting } \\
\text { and Economics }\end{array}$ & 297 \\
\hline $\begin{array}{l}\text { Lafond R., } \\
\text { Roychowdhury S. }\end{array}$ & Managerial ownership and accounting conservatism & 2008 & $\begin{array}{l}\text { Journal of Accounting } \\
\text { Research }\end{array}$ & 225 \\
\hline $\begin{array}{l}\text { Roychowdhury S., } \\
\text { Watts R.L. }\end{array}$ & $\begin{array}{l}\text { Asymmetric timeliness of earnings, market-to-book and } \\
\text { conservatism in financial reporting }\end{array}$ & 2007 & $\begin{array}{l}\text { Journal of Accounting } \\
\text { and Economics }\end{array}$ & 220 \\
\hline $\begin{array}{l}\text { Krishnan G.V., } \\
\text { Visvanathan G. }\end{array}$ & $\begin{array}{l}\text { Does the SOX definition of an accounting expert matter? } \\
\text { The association between Audit committee directors' } \\
\text { accounting expertise and accounting conservatism }\end{array}$ & 2008 & $\begin{array}{c}\text { Contemporary } \\
\text { Accounting Research }\end{array}$ & 212 \\
\hline $\begin{array}{l}\text { García Lara J.M., García } \\
\text { Osma B., Penalva F. }\end{array}$ & Accounting conservatism and corporate governance & 2009 & $\begin{array}{l}\text { Review of Accounting } \\
\text { Studies }\end{array}$ & 174 \\
\hline Wittenberg-Moerman R. & $\begin{array}{c}\text { The role of information asymmetry and financial } \\
\text { reporting quality in debt trading: Evidence from the } \\
\text { secondary loan market }\end{array}$ & 2008 & $\begin{array}{l}\text { Journal of Accounting } \\
\text { and Economics }\end{array}$ & 151 \\
\hline Kim J.-B., Zhang L. & $\begin{array}{c}\text { Accounting Conservatism and Stock Price Crash Risk: } \\
\text { Firm-level Evidence }\end{array}$ & 2016 & $\begin{array}{c}\text { Contemporary } \\
\text { Accounting Research }\end{array}$ & 148 \\
\hline Nikolaev V.V. & Debt covenants and accounting conservatism & 2010 & $\begin{array}{l}\text { Journal of Accounting } \\
\text { Research }\end{array}$ & 145 \\
\hline $\begin{array}{l}\text { Dietrich J.R., Muller III } \\
\text { K.A., Riedl E.J. }\end{array}$ & Asymmetric timeliness tests of accounting conservatism & 2007 & $\begin{array}{l}\text { Review of Accounting } \\
\text { Studies }\end{array}$ & 138 \\
\hline Altamuro J., Beatty A. & $\begin{array}{l}\text { How does internal control regulation affect financial } \\
\text { reporting? }\end{array}$ & 2010 & $\begin{array}{l}\text { Journal of Accounting } \\
\text { and Economics }\end{array}$ & 135 \\
\hline Ahmed A.S., Duellman S. & $\begin{array}{c}\text { Managerial Overconfidence and Accounting } \\
\text { Conservatism }\end{array}$ & 2013 & $\begin{array}{l}\text { Journal of Accounting } \\
\text { Research }\end{array}$ & 127 \\
\hline Francis J.R., Martin X. & Acquisition profitability and timely loss recognition & 2010 & $\begin{array}{l}\text { Journal of Accounting } \\
\text { and Economics }\end{array}$ & 127 \\
\hline Ramalingegowda S., Yu Y. & Institutional ownership and conservatism & 2012 & $\begin{array}{l}\text { Journal of Accounting } \\
\text { and Economics }\end{array}$ & 121 \\
\hline $\begin{array}{l}\text { Gigler F., Kanodia C., } \\
\text { Sapra H., Venugopalan R. }\end{array}$ & $\begin{array}{l}\text { Accounting conservatism and the efficiency of debt } \\
\text { contracts }\end{array}$ & 2009 & $\begin{array}{l}\text { Journal of Accounting } \\
\text { Research }\end{array}$ & 115 \\
\hline $\begin{array}{l}\text { García Lara J.M., García } \\
\text { Osma B., Penalva F. }\end{array}$ & Accounting conservatism and firm investment efficiency & 2016 & $\begin{array}{l}\text { Journal of Accounting } \\
\text { and Economics }\end{array}$ & 106 \\
\hline Qiang X. & $\begin{array}{c}\text { The effects of contracting, litigation, regulation, and tax } \\
\text { costs on conditional and unconditional conservatism: } \\
\text { Cross-sectional evidence at the firm level }\end{array}$ & 2007 & Accounting Review & 103 \\
\hline
\end{tabular}


Next, the most cited research on the topic of AC research is: "The relevance of the value relevance literature for financial accounting standard setting: Another view", written by Barth et al. (2001). The authors contended that to assess the information quality of the organization, value relevance is one of many traits. So the study concludes that value relevance is only a part of evaluating the merits of AC. The findings confirmed that the value relevance is important only to gauge the impact of conservatism from the equity market perspective and not from a contracting standpoint.

The study by Khan and Watts (2009) also gained many citations from the researchers' community on the topic of AC. Their research has constructed a model to measure conditional conservatism based on differential timeliness measure, where the greater value of slope indicates more conservatism than the other positive sample points. They argued that both intercept and slope value in their model are based on the linear function of the market to book value ratio (MTB), size, and leverage.

\section{Discussion and Future Research}

This study demonstrates a bibliometric analysis of AC literature between 1994 and 2019 from the Scopus database. The current paper provides a general overview of AC to determine the prevalent issues, research trends, and main outcomes. Therefore, this study provides a literature review by summarizing the available research and findings published to date. To sum up, this research offers a guide to new explorers in the AC field, facilitating them with firsthand knowledge regarding $\mathrm{AC}$ past, present, and future to develop a worthy literature review or build interesting empirical models.

The analysis of the evolution of citations and publications on AC allows us to appreciate the development of the field enabling the literary world to know the years with the highest number of citations and publications. The present study also sheds light on this field's research trends and popular matters. Still, many research opportunities exist on the topic of AC. The researchers need to develop a proper conceptualization of accounting conservatism. The existing measures have noise and do not reflect conservatism inclusively (Ball and Shivakumar 2005; Basu et al. 2001). In the future, their need to have the means to differentiate between conditional and non-conditional conservatism (Beatty et al. 2008). Past researchers have studied the impact of AC alone on an organization's different fundamental performance measures; in the future, we suggest that AC should be studied to see its holistic impact on an organization in conjunction with other governance measures. Additionally, managers' incentives for conservative accounting must be considered, and it needs to be explored that under what conditions managers are more inclined to conventional accounting (Cao and Pham 2021). In the recent past, changes have been made in regulations by FASB and IASB regardjacking conservatism (Dhaliwal et al. 2014; FASB 1975, 2009), so researchers need to check changes in regulations' impact on the use of conservatism by accountants and its effects on the organizations.

Furthermore, it will be an exciting study to see how AC impacts the bankruptcy risk of an organization and how it plays a vital role in checking managerial activities (Gao et al. 2020). The specialization of audit committee members' effect on accounting conservatism needs to be investigated, as, in previous studies, managerial attributes are linked with accounting conservatism. Still, audit committee members' qualifications may impact the use of AC by the organizations; it needs to be further studied. There is always a need for studies on the costs and benefits of AC on the organization's future, so we recommend a study on these aspects to fully understand the concept of accounting conservatism.

We hope to see more research on $\mathrm{AC}$, integrating academia, practitioners, and the process-based approach to AC. The studies focusing on the effect of the overall AC system rather than individual practices may have more impact on the organization, ultimately making this world a better place to live in.

The topic is relevant, and its diffusion occurs mostly in symposiums, conferences, annual scholarly meetings. It seems that publishing papers in a relatively new field are easier because there is still much to discover. 
It has been noted that authors from the European and South Asian countries have not contributed too much, so the authors from European and South Asian countries should add to the literature of AC in more depth (Healy and Wahlen 1999; Holthausen and Watts 2001; Hui et al. 2009; Jackson and Liu 2010). This area of AC deserves more attention as employees are the most important stakeholders of any organization. They contribute a lot to the success of any organization in the form of profitability, competitive advantage, organizational success, and innovation. As far as Asian countries are concerned, India is the one that has a higher number of publications and citations. So, other countries from Asia should also focus on this stream of research.

The study result has implications for practitioners as well as for researchers in the field of accounting conservatism. Firstly, from this study, we can suggest some future research opportunities on the topic and helps to converge the interests of academia and industry (Kim et al. 2013; Kothari et al. 2010; Lafond and Roychowdhury 2008). The current research on the topic provides opportunities to the researchers to understand the extent to which the topic addressed the issue and its relevance to the practice. For example, agency issues are the point of concern for shareholders (Lara et al. 2009; Nikolaev 2010). Hence, a study on accounting conservatism explains how different accounting practices help reduce the agency problem and its importance to converge the objectives of agent and principal in the agency relationship.

The most important contribution of this study is the summarization of the studies on the particular topic. It informs future researchers about the existing and recent work on the subject, which will help them target the top-notch journal for their publications. This study is also helpful to journal editors, as this research provides an insight for future research growth on the topic. The students can also get this contribution to obtain information about professors and universities working on the issue. It will help students to identify and select the best universities contributing to the field. Policymakers can also get help to pursue their accounting policies from this study, and they can get an idea of new trends in firms and of how they evolve with time.

\section{Conclusions and Limitations}

The last few decades have seen substantial growth in the AC field, reflecting its significance and competitiveness in the current academic world. Hence, AC makes up a topic that has been developing and currently entails greater relevance for both practitioners and academics (Collazo-Reyes 2014). Although the concept of AC is mostly employed as an independent variable where its theoretical background remains under construction, there is a broad heterogeneity concerning the outcomes of AC. It might be explained by the diversity of scholars approaching this issue, which in turn reflects the keen interest that this research topic has currently attained.

This research also offers several limitations. First, the present research includes academic material published in Scopus. More studies on AC were published in other databases that cannot be accessed through the Scopus database (Farrukh et al. 2020). Second, the publication number and citation index are frequently employed to measure quantity and quality, respectively, despite the actual document quality. The influence and impact of the researcher can be evaluated well through his citation numbers rather than article numbers (Podsakoff et al. 2008). However, only considering the importance or relevance of an author often convinces other authors to develop a particular or decisive view regarding their content or cite that specific author without reading his/her articles (Albort-Morant and Ribeiro-Soriano 2016). Third, the method being used in this study can encounter different authors with the same names. Fourth, although the findings provide a picture of the prevailing scenario, this may change over time, particularly for those published in the last few years, as they still have to grow considerably regarding the citations (Fagerberg et al. 2012). Finally, generalizing this study conclusion can be a limitation as the present research has been developed within a specific field: AC. 
In the future, researchers might conduct a bibliometric analysis employing other databases, such as Web of Sciences (Gaviria-Marin et al. 2018). Future studies can arrive at a better understanding of AC by collecting more information on this topic. Future studies could also employ a structural indicator, which measures the relationships between authors, knowledge areas, and publications using sociograms. Moreover, it could be interesting to analyze the current topics and their evolution over time.

Author Contributions: Conceptualization, U.B. and A.R.; methodology, J.N.M.; software, R.M.D.; validation, A.R., M.N.M. and M.R.; formal analysis, J.N.M.; investigation, A.B.C.; resources, U.B.; data curation, U.B.; writing—original draft preparation, A.R.; writing—review and editing, J.N.M.; visualization, R.M.D.; supervision, A.R.; project administration, M.R. All authors have read and agreed to the published version of the manuscript.

Funding: This research received no external funding.

Informed Consent Statement: Not applicable.

Data Availability Statement: Data are available upon request from authors.

Conflicts of Interest: The authors declare no conflict of interest.

\section{References}

Ahmed, Anwer S., and Scott Duellman. 2013. Managerial overconfidence and accounting conservatism. Journal of Accounting Research 51: 1-30. [CrossRef]

Ahmed, Imran, Misbah Ahmad, Joel J.P.C. Rodrigues, Gwanggil Jeon, and Sadia Din. 2021. A deep learning-based social distance monitoring framework for COVID-19. Sustainable Cities and Society 65: 102571. [CrossRef]

Albort-Morant, Gema, and Domingo Ribeiro-Soriano. 2016. A bibliometric analysis of international impact of business incubators. Journal of Business Research 69: 1775-9. [CrossRef]

Ball, Ray, and Lakshmanan Shivakumar. 2005. Earnings quality in UK private firms: Comparative loss recognition timeliness. Journal of Accounting and Economics 39: 83-128. [CrossRef]

Barth, Mary E., William H. Beaver, and Wayne R. Landsman. 2001. The relevance of the value relevance literature for financial accounting standard setting: Another view. Journal of Accounting and Economics 31: 77-104. [CrossRef]

Basu, Sudipta. 1997. The conservatism principle and the asymmetric timeliness of earnings1. Journal of Accounting and Economics 24: 3-37. [CrossRef]

Basu, Sudipta, Lee-Seok Hwang, and Ching-Lih Jan. 2001. Differences in Conservatism between Big Eight and Non-Big Eight Auditors. Available online: http: / / ssrn.com/abstract=2428836 (accessed on 1 June 2021).

Beatty, Anne, Joseph Weber, and Jeff Jiewei Yu. 2008. Conservatism and Debt. Journal of Accounting and Economics 45: 154-74. [CrossRef]

Björk, Tomas, Agatha Murgoci, and Xun Yu Zhou. 2014. Mean-variance portfolio optimization with state-dependent risk aversion. Mathematical Finance: An International Journal of Mathematics, Statistics and Financial Economics 24: 1-24. [CrossRef]

Boulton, Thomas J., Scott B. Smart, and Chad J. Zutter. 2017. Conservatism and international IPO underpricing. Journal of International Business Studies 48: 763-85. [CrossRef]

Bouyssou, Denis, and Thierry Marchant. 2011. Bibliometric rankings of journals based on impact factors: An axiomatic approach. Journal of Informetrics 5: 75-86. [CrossRef]

Cadavid Higuita, Lorena, Gabriel Awad, and Carlos Jaime Franco Cardona. 2012. A bibliometric analysis of a modeled field for disseminating innovation. Estudios Gerenciales 28: 213-36. [CrossRef]

Cao, Viet Nga, and Anh Viet Pham. 2021. Behavioral spillover between firms with shared auditors: The monitoring role of capital market investors. Journal of Corporate Finance 68: 101914. [CrossRef]

Chang, Xin, Gilles Hilary, Jun-koo Kang, and Wenrui Zhang. 2013. Does accounting conservatism impede corporate innovation. SSRN Electronic Journal. [CrossRef]

Collazo-Reyes, Francisco. 2014. Growth of the number of indexed journals of Latin America and the Caribbean: The effect on the impact of each country. Scientometrics 98: 197-209. [CrossRef]

Daim, Tugrul U., Guillermo Rueda, Hilary Martin, and Pisek Gerdsri. 2006. Forecasting emerging technologies: Use of bibliometrics and patent analysis. Technological Forecasting and Social Change 73: 981-1012. [CrossRef]

De Bakker, Frank G. A., Peter Groenewegen, and Frank Den Hond. 2005. A bibliometric analysis of 30 years of research and theory on corporate social responsibility and corporate social performance. Business \& Society 44: 283-17.

Dhaliwal, Dan, Shawn Huang, Inder K. Khurana, and Raynolde Pereira. 2014. Product market competition and conditional conservatism. Review of Accounting Studies 19: 1309-45. [CrossRef]

Donthu, Naveen, Satish Kumar, and Debidutta Pattnaik. 2020. Forty-five years of Journal of Business Research: A bibliometric analysis. Journal of Business Research 109: 1-14. [CrossRef] 
Duque-Oliva, Edison Jair, Amparo Cervera Taulet, and Carlos Rodríguez Romero. 2006. Estudio bibliométrico de los modelos de medición del concepto de calidad percibida del servicio en Internet. INNOVAR. Revista de Ciencias Administrativas y Sociales 1: $223-43$.

Durieux, Valérie, and Pierre Alain Gevenois. 2010. Bibliometric indicators: Quality measurements of scientific publication. Radiology 255: 342-51. [CrossRef]

Fagerberg, Jan, Morten Fosaas, and Koson Sapprasert. 2012. Innovation: Exploring the knowledge base. Research Policy 41: $1132-53$. [CrossRef]

Farrukh, Muhammad, Fanchen Meng, and Ali Raza. 2020. Twenty-Seven Years of Sustainable Development Journal: A Bibliometric Analysis. Sustainable Development 28: 1725-37. [CrossRef]

Farrukh, Muhammad, Ali Raza, Sarfaraz Javed, and Jason Wai Chow Lee. 2021. Twenty Years of Green Innovation Research: Trends and Way Forward. World Journal of Entrepreneurship, ahead-of-print. [CrossRef]

FASB. 1975. Financial Accounting Standards Board (FASB). Accountingfor Contingencies. Statement of Financial Accounting Standards No. 5. Norwalk: FASB.

FASB. 2009. Financial Accounting Standards Board (FASB). Intangibles-Goodwill and Other. Accounting Standards Codification 350. Norwalk: FASB.

FASB. 2010. Financial Accounting Standards Board (FASB). Conceptual Framework for Financial Reporting: Chapter 1. The Objective of General Purpose Financial Reporting, and Chapter 3, Qualitative Characteristics of Useful Financial Reporting Information. Statement of Financial Accounting Concepts No. 8. Norwalk: FASB.

Feltham, Gerald A., and James A. Ohlson. 1995. Valuation and clean surplus accounting for operating and financial activities. Contemporary Accounting Research 11: 689-731. [CrossRef]

Francis, Bill, Iftekhar Hasan, and Qiang Wu. 2013. The benefits of conservative accounting to shareholders: Evidence from the financial crisis. Accounting Horizons 27: 319-46. [CrossRef]

Gao, Weiwei, Ting Cao, and Zhen Huang. 2020. Do outsiders listen to insiders? The role of government support in market reactions to earnings announcements. Managerial and Decision Economics 42: 781-95. [CrossRef]

Garfield, Eugene. 2006. Citation indexes for science. A new dimension in documentation through association of ideas. International Journal of Epidemiology 35: 1123-7. [CrossRef]

Gaviria-Marin, Magaly, Jose M. Merigo, and Simona Popa. 2018. Twenty years of the Journal of Knowledge Management: A bibliometric analysis. Journal of Knowledge Management 22: 1655-87. [CrossRef]

Gigler, Frank, Chandra Kanodia, Haresh Sapra, and Raghu Venugopalan. 2009. Accounting conservatism and the efficiency of debt contracts. Journal of Accounting Research 47: 767-97. [CrossRef]

Glover, Jonathan C., and Haijin H. Lin. 2018. Accounting conservatism and incentives: Intertemporal considerations. The Accounting Review 93: 181-201. [CrossRef]

Gu, Zhouyang, Fanchen Meng, and Muhammad Farrukh. 2021. Mapping the Research on Knowledge Transfer: A Scientometrics Approach. IEEE Access 9: 34647-59. [CrossRef]

Guay, Wayne, and Robert Verrecchia. 2006. Discussion of an economic framework for conservative accounting and Bushman and Piotroski 2006. Journal of Accounting and Economics 42: 149-65. [CrossRef]

Healy, Paul M., and James M. Wahlen. 1999. A review of the earnings management literature and its implications for standard setting. Accounting Horizons 13: 365-83. [CrossRef]

Ho, Simon S., Annie Yuansha Li, Kinsun Tam, and Feida Zhang. 2015. CEO gender, ethical leadership, and accounting conservatism. Journal of Business Ethics 127: 351-70. [CrossRef]

Holthausen, Robert W., and Ross L. Watts. 2001. The relevance of the Value-relevance Literature for Financial Accounting Standard Setting. Journal of Accounting and Economics 31: 3-75. [CrossRef]

Hui, Kai Wai, Steve Matsunaga, and Dale Morse. 2009. The impact of conservatism on management earnings forecasts. Journal of Accounting and Economics 47: 192-207. [CrossRef]

Jackson, Scott B., and Xiaotao Liu. 2010. The Allowancefor Uncollectible Accounts, Conservatism, and Earnings Management. Journal of Accounting Research 48: 565-601. [CrossRef]

Kabir, M. Humayun, and Fawzi Laswad. 2014. The behaviour of earnings, accruals and impairment losses of failed New Zealand finance companies. Australian Accounting Review 24: 262-75. [CrossRef]

Kessler, Maxwell Mirton. 1963. Comparison of the results of bibliographic coupling and analytic subject indexing. American Documentation 16: 223-33. [CrossRef]

Khalilov, Akram, and Beatriz Garcia Osma. 2020. Accounting conservatism and the profitability of corporate insiders. Journal of Business Finance and Accounting 47: 333-64. [CrossRef]

Khan, Mozaffar, and Ross L. Watts. 2009. Estimation and empirical properties of a firm-year measure of accounting conservatism. Journal of Accounting and Economics 48: 132-50. [CrossRef]

Kim, Yongtae, Siqi Li, Carrie Pan, and Luo Zuo. 2013. The Role of Accounting Conservatism in the Equity Market: Evidence from Seasoned Equity Offerings. The Accounting Review 88: 1327-56. [CrossRef]

Kothari, S. P., Karthik Ramanna, and Douglas J. Skinner. 2010. Implications for GAAP from an Analysis of Positive Research in Accounting. Journal of Accounting and Economics 50: 246-86. [CrossRef] 
Lafond, Ryan, and Sugata Roychowdhury. 2008. Managerial Ownership and Accounting Conservatism. Journal of Accounting Research 46: 101-35. [CrossRef]

Lara, Juan Manuel García, Beatriz García Osma, and Fernando Penalva. 2009. Accounting conservatism and corporate governance. Review of Accounting Studies 14: 161-201. [CrossRef]

Lara, Juan Manuel García, Beatriz García Osma, and Fernando Penalva. 2016. Accounting conservatism and firm investment efficiency. Journal of Accounting and Economics 61: 221-38. [CrossRef]

Li, Jing. 2013. Accounting Conservatism and Debt Contracts: Efficient Liquidation and Covenant Renegotiation. Contemporary Accounting Research 30: 1082-98. [CrossRef]

Merigó, José M., Christian A. Cancino, Freddy Coronado, and David Urbano. 2016. Academic research in innovation: A country analysis. Scientometrics 108: 559-93. [CrossRef]

Nawaz, Kalsoom, Hafiza Anum Saeed, and Tanveer Aslam Sajeel. 2020. Covid-19 and the State of Research from the Perspective of Psychology. International Journal of Business and Psychology 2: 35-44.

Nerur, Sridhar P., Abdul A. Rasheed, and Vivek Natarajan. 2008. The intellectual structure of the strategic management field: An author co-citation analysis. Strategic Management Journal 29: 319-36. [CrossRef]

Nikolaev, Valeri V. 2010. Debt Covenants and Accounting Conservatism. Journal of Accounting Research 48: 51-89. [CrossRef]

Persson, Olle, Rickard Danell, and J. Wiborg Schneider. 2009. How to use Bibexcel for various types of bibliometric analysis. Celebrating Scholarly Communication Studies: A Festschrift for Olle Persson at His 60th Birthday 5: 9-24.

Pilkington, Alan, and Jack Meredith. 2009. The evolution of the intellectual structure of operations management-1980-2006: A citation/co-citation analysis. Journal of Operations Management 27: 185-202. [CrossRef]

Podsakoff, Philip M., Scott B. MacKenzie, Nathan P. Podsakoff, and Daniel G. Bachrach. 2008. Scholarly influence in the field of management: A bibliometric analysis of the determinants of university and author impact in the management literature in the past quarter century. Journal of Management 34: 641-720. [CrossRef]

Small, Henry. 1973. Co-citation in the scientific literature: A new measure of the relationship between two documents. Journal of the American Society for Information Science 24: 265-69. [CrossRef]

Sterling, Robert. R. 1982. The Theory of the Measurement of Enterprise Income. London: Routledge, pp. $233-82$.

Van Eck, Nees Jan, and Ludo Waltman. 2010. Software survey: VOSviewer, a computer program for bibliometric mapping. Scientometrics 84: 523-38. [CrossRef]

Watts, Ross L. 2003. Conservatism in accounting part I: Explanations and implications. Accounting Horizons 17: 207-21. [CrossRef]

$\mathrm{Wu}$, Yihua, Muhammad Farrukh, Ali Raza, Fanchen Meng, and Imtiaz Alam. 2021. Framing the Evolution of the Corporate Social Responsibility and Environmental Management Journal. Corporate Social Responsibility and Environmental Management. [CrossRef] 